\title{
A Critical Review on Regional Integration Processes in East Asia
}

\author{
Min Ha Lee*, Inkyo Cheong**
}

\begin{abstract}
The major economies of East Asia, namely Japan and the Four Asian Tigers, have always prioritized the WTO-led multilateral trade liberalization over other trade arrangements primarily due to their unique economic structure with a high dependency on the world's major markets such as the US. Along the same line, even the huge blow from the Asian Financial Crisis in 1997 only managed to trigger a few initiatives to aide East Asian regional integration while being led by different centering bodies, APEC and ASEAN. These dispersed efforts naturally resulted in no realistically significant achievements in the light of 'integration' until the present day. Under these circumstances, East Asia now faces a second opportunity to achieve its economic independence from the extra-regional influences via regionalization: the 2009 Global Credit Crunch. This paper hereupon critically reviews the actual progress and the likely impacts of the current global recession on the East Asian region.
\end{abstract}

Keywords: East Asian regionalization, ASEAN, APEC, Global Credit Crunch

Submission Date: 6/30/2011 Revision Date: 8/24/2011 Acceptance Date: 8/24/2011

* Research Associate, Center for International Development, Korea Development Institute.

Tel:82-2-958-4168, E-mail : minha.lee@kdi.re.kr

** Director, JRI, Inha University, Tel:82-32-860-7785, E-mail:inkyo@inha.ac.kr 


\section{Introduction}

The fall of the Berlin Wall signaled the end of 'traditional' international relations and forced state policy makers to re-establish their positions in newly defined 'spheres of influence'. The concept of region, measured by geographical proximity, has thus re-appeared in the designing of foreign policies and international economic relations, particularly, to the extent that an inter-locking, ever-growing network of regional trade agreements (RTAs) has become a significant pillar of today's global trading environment. On the other hand, 'the elimination of discriminatory treatment within international trade systems has also made significant progress globally since the birth of the General Agreement on Tariffs and Trade (GATT) in 1947. The conflicting characteristics of these two ongoing trade mechanisms have, consequently, become the most controversial issue of the times. In particular, the discriminative nature of the later-introduced regional arrangements resulted in an ongoing debate on whether regionalism is a 'building-block' or a 'stumbling-block' in multilateral trading systems. However, it now seems to have been recognized as the righteously-pursued ultimate goal. Under the current circumstances in which the world is busy challenging, defending or creating RTAs, East Asia ${ }^{1)}$ interestingly remained devoted to the multilateral negotiations under the GATT/WTO regime until the late 1990s. Furthermore, East Asian countries have thus far only pursued bilateral free trade agreements (FTAs) since just after the 1997 Asian Financial Crisis, with no substantial progress regarding region-wide economic integration in East Asia and in the Asia Pacific region. This fact is very ironic considering the volume of research, which has confirmed that substantial economic and political gains can be expected from an East Asian regional integration. Many scholars among the political elites within the region have listed three differences: historical experiences, ideologies and expectations as the main causes of the vast gap between the theory and the practice of economic cooperation in the Asia Pacific region. Higgott and Stubbs (1995), in particular, pinpointed two distinct conceptual differences in defining the region itself, the boundaries and the form of cooperation, as the issues-to-be-settled prior to further regionalization progresses in East Asia.

Since its first introduction in the 1980's and 1990's, when scholars gradually began to ditch the antiquated, Western-centric referent 'Far East' for the region, the distinction between 'East Asia' and 'Asia' was increasingly used to specify where exactly on the vast continent the profound economic transformation was actually occurring on a specific regional scale. ${ }^{2)}$ Yet, the boundaries of East Asia still remain unclear: while the financial

\footnotetext{
1) East Asia, for the purpose of this paper, is defined as ASEAN +3 countries

2) Christopher M. Dent (2008), Ch.1
} 
crisis that hit many countries in the region in 1997 was addressed as the Asian Financial Crisis of 1997, the Summit covering a larger region with 16 countries of 10 ASEAN countries, 3 Northeast Asian countries and 3 more from elsewhere - India (Asia), Australia (Oceania) and New Zealand (Oceania) - launched in 2005 is named the East Asian Summit (EAS).

One of the explanations for such blurred boundaries of East Asia is that the concept was never properly developed internally. Linking to the distinctive characteristics of the bottom-up, market-driven regionalization ${ }^{3)}$ process, the region, like the American continent, has established a business network to satisfy the growing economic interdependency without impairing its national sovereignty. Under these circumstances, East Asia failed to develop its own regional identity while Europe's regionalism4) succeeded in mapping the boundaries of 'Europe' through the government-driven institutional integration processes. Counting undefined boundaries within the region, East Asia refers to 13 countries of ASEAN+35) for the purpose of this paper as mentioned before.

Due to the current undefined boundaries of East Asia, however, the region is further facing difficulties from the very first process of selecting the initial members of the regional integration. Japan's preference for the ASEAN+6 FTA has its basis on the EAS, ${ }^{6}$ ) while the majority of the remaining parties would like to narrow the scope down to 13 initial members of the ASEAN+3 Summit which was launched at the outbreak of the 1997 Asian Financial Crisis. To complicate the situation even further, the US has been driving for the APEC FTA to overwrite any exclusive-East Asian integration initiatives related to its long history of deep involvement in the region.

The downside of the competitive simultaneous progress of these three integrative mechanisms is that, although the nature of all three is distinctively economic in flavor rather than political, none has yet to be significantly developed. [Figure 1] clearly demonstrates the evidently slower regionalization process in East Asia. This suggests the possibilities of the involved countries being captured in the current game-like situation,7) in

3) Regionalization is a regional integration process that is linked to the processes of economic integration among more than two states which, while state policies remain highly influential, are essentially the uncoordinated consequences of private sector activities

4) Regionalism, in accordance with recent academic research, refers to the political process in which more than two states drive cooperative initiatives

5) Refers to The Association of Southeast Asian Nations, launched in August, 1967 (Indonesia, Malaysia, the Philippines, Singapore, Thailand, Brunei, Cambodia, Laos, Myanmar and Vietnam), plus three Northeast Asian countries (China, Japan and Korea)

6) The ASEAN+6 FTA is called the Comprehensive Economic Partnership in East Asia (CEPEA)

7) Game theory attempts to mathematically capture behavior in strategic situations, in which an individual's success in making choices depends on the choices of others. While initially developed to analyze competitions in which one individual does better at another's expense (zero sum game), it has been 
which their policies change in response to the other players' moves. Accordingly, the bilateral trade arrangements have proliferated in the region at such a rapid pace since the 1997 Asian Financial Crisis that the East Asian region is now facing a high risk of both the Spaghetti Bowl Effect ${ }^{8}$ ) and, even worse, hub-and-spoke bilateralism.9) The two most foreseeable issues which could arise from the current structure are, first, economically inferior output for a region as a whole by encouraging trade diversion toward the hub economy. Wonnacott (1996) has theoretically proved that a region-wide FTA is more advantageous than a hub-and-spoke system for various economic reasons. The other issue is that, as Findlay (2000) concluded, the biggest danger of this hub-and-spoke-ism is the strong incentive for economies to race for the 'hub' position. In realistic terms, as the share of the benefits from integration is bound to be biased toward the hub economy, while the spoke economies are to be marginalized both economically and politically; the evolution of political tension against the hub economy is inevitable. Consequently, every country which is involved will naturally aim to become the regional FTA hub country by covering the region with layers of discriminatory structures and underlying conflicts.

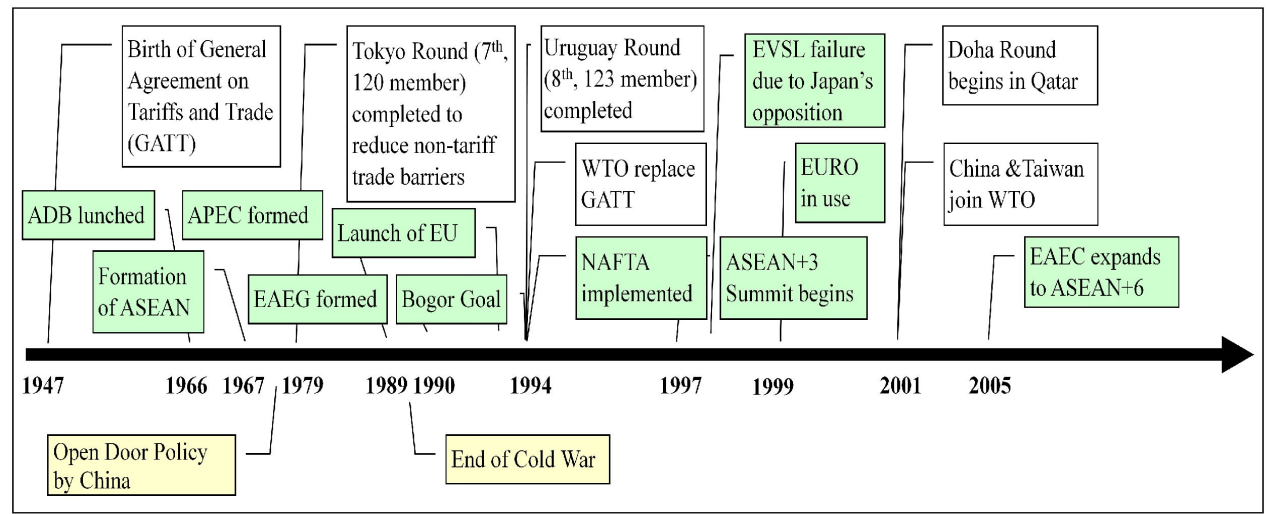

Figure 1.

Timeline of Globalization vs. Regionalization ${ }^{10)}$

expanded to treat a wide class of interactions, which are classified according to several criteria. Today "game theory has become a short of umbrella or 'unified field' theory for the rational side of social science, where 'social' is interpreted broadly, to include human as well as non-human players" (Aumann 1987)

8) This term is first introduced by Jagdish Bhagwati to describe the web of customs unions, common markets, regional and bilateral free trade areas and other preferential trade agreements which have dominated international trade in recent years. The negative externalities associated with the spaghetti bowl are overlapping and potentially contradictory obligations leading to increased complexity and costs for businesses and administrators (Bhagwati, 2002:112-13).

9) It is a system of connections arranged like a chariot wheel, in which all traffic moves along spokes connected to the hub at the center.

10) Timeline drawn by Minha Lee 
We must acknowledge the reality that regional integration is not an outcome of natural progress, which could be eventually achieved with dispersed efforts. It is fair to state that East Asia will not be able to accomplish any kind of institutional regionalization without first reaching a consensus on the scope of the regional integration. Considering the recent expansion of the East Asian Economic Caucus (EAEC) ${ }^{11}$ ) to include Australia, India and New Zealand, from the originally proposed ASEAN+3, in2005, East Asian policy makers, de facto, have three options to choose from: ASEAN+3, ASEAN+6 and APEC. This paper will critically review the progression of the three simultaneously ongoing East Asian economic cooperation mechanisms in order to understand the current status of East Asian regional integration.

\section{East Asian Regionalization}

Building upon the basic circumstances surrounding the regional integration processes in East Asia, this chapter will thoroughly analyze the progress from a historical perspective to understand the uniquely complicated situation that East Asia is currently facing. By doing so, this paper aims to examine the possibility of this region achieving 'truly' regional integration against Beeson's market model12) in spite of everything.

Moreover, we need to deal with a regionalism that in practice is much more multifaceted and multidimensional than in the past. States now engage in any number of overlapping regional endeavors without feeling that there may be contradictions in such process (Breslin and Higgott, 2000:339)

\subsection{APEC-driven Trans-regional Cooperation}

The first one of the three options, open regionalism, ${ }^{13}$ ) which was offered by APEC,

11) The current ASEAN +3 mechanism has no direct relationship with the initiative of former Malaysian Prime Minister Mahatir's EAEC, but the ideas share common factors such as the identity of East Asia. Because of this, this paper uses the EAEC as the meaning of a regional economic integration body in East Asia.

12) Beeson (2002): The market model of regional integration assumes that institutional development is driven by a rational and functional response of governments who 'supply' regional institutions to match the demand for regional cooperation as economic integration or the opening of markets deepens. This analysis, however, is still imperfect as the importance of different types of 'regional political projects' and the 'differential national' consequences of each regional integration strategy are underestimated.

13) Open Regionalism, often called soft regionalism as well, represents an effort to resolve one of the central problems of contemporary trade policy: how to achieve compatibility between the explosion of regional 
has the longest development history and goes as far back as the early $20^{\text {th }}$ Century. During the Cold War, when institutional arrangements among nations remained remote in the Asia-Pacific, the self-defining region did not exist in East Asia. Independent governments were preoccupied with survival issues and the region itself was divided into two opposite spheres which were controlled by the Soviet Union and the US. Constant tensions meant that regional building was not an option until the turn of the century. Meanwhile non-Governmental actors, such as businessmen and scholars, opened informal networks to pave the way towards Asia-Pacific economic cooperation underlying foundations of today's APEC. ${ }^{14)}$ The establishment of the Pacific Basin Economic Council (PBEC, 1967), the creation of the Pacific Trade and Development Conference (PAFTAD, 1969), and the development of the Pacific Economic Cooperation Conference (PECC, now Council) ${ }^{15}$ ) through the 1980's are just a short list of the main milestones that eventually culminated in the inauguration of APEC in November 1989 with the 12 founding members: Australia, Canada, Japan, Korea, New Zealand, the US and, at that time, six members of ASEAN (Brunei, Indonesia, Malaysia, the Philippines, Singapore and Thailand).

Under these circumstances, APEC proclaimed unequivocal support for GATTconsistent free trade and investment (Trade and Investment Liberalization and Facilitation, TILF) as well as economic and technical cooperation (ECOTECH) following the multilateral trade liberalization policy of the US at that time, by rejecting the block-building process. As Gill (1994) puts it, a belief in market-led integration lies at the center of APEC, essentially being a creature on the rise of economic liberalism. Peter Drysdale and Ross Garnaut (1993) further expanded this characteristic into a 'General Theory of Integration' for the Pacific against which European Community's institutionalists' integration, or a discriminatory model of regional economic cooperation, was contrasted. Such dedicated devotion was highlighted by the most impressive landmark declaration of the Bogor Goa 116) (1994) which promotes free trade for developed and developing countries between

trading arrangements around the world and the global trading system as embodied in the WTO. It has first been adopted as a fundamental principle of the APEC, of which Bogor Goal has ambitiously announced an establishment of the most far-reaching trade agreement in history by 2020 . Yet neither APEC nor any other official body has defined the term 'open regionalism' clearly and has not been any explicit application of the principle to date.

14) Choi (2004)

15) One of the informal networks among non-governmental actors operated in 1960s to develop new strategies for Asia-Pacific economic cooperation. Later it evolved into its unique tripartite structure comprising representatives from business, academia and government, which laid foundations for the establishment of APEC in 1989.

16) Asia-Pacific Economic Cooperation, now a forum for 21 Pacific Rim countries, was originally established to promote open regionalism through voluntary unilateral and concerted liberalization of trade and investment in 1989. At the second Economic Leaders' meeting, held in Bogor, Indonesia in 1994, the leaders agreed to achieve free and open trade and investment in the region no later than 2020. 
2010- 2020, respectively, with which APEC strongly opposed the inward-looking trading bloc and embraced open regionalism to share the benefits of liberalization with non-members. In addition to the 'openness' of the scope of the trade liberalization, Bogor Goal is unique from other pre-concluded regional arrangements in the sense that it emphasized the voluntary liberalization process, implying an unilateral dimension, in which either individual member economies or all members are collectively expected to announce and implement their own liberalization and facilitation programs. This modality of liberalization and facilitation is captured in the term concerted unilateralism. 17)

The concept of open regionalism was first suggested by PECC in the early 1980's, asserting that overwhelming benefits could be accrued from an open and multilateral trading system. Such a role of open regionalism for the promotion of the multilateral liberalization process was further supported by Renato Ruggiero, the first Director General of the WTO, who described it as "the gradual elimination of internal barriers to trade within a regional grouping at more or less the same rate and on more or less the same timetable as the lowering of barriers towards non-members, which would, in practice as well as in law, be generally consistent with the Most-Favored-Nation (MFN) principle of GATT." 18) Furthermore, Garnaut (1996) attempted to demonstrate the merits of unilateral and joint liberalization, i.e. open regionalism, by applying the matrix of the prisoners' delight, analogous to the perception of prisoners' dilemma but with the beneficial pay-offs accruing from joint liberalization as shown in [Figure 2]. Following the same logic of the prisoner's dilemma, Garnaut argued that all participants would be able to enjoy the maximum benefits if they could unilaterally liberalize trade while trusting others to voluntarily do the same. Once the whole world becomes a complete pie of liberalization, all economic players will be able to achieve their best output while realizing economies of scale (producers) and perfect competition (consumers).

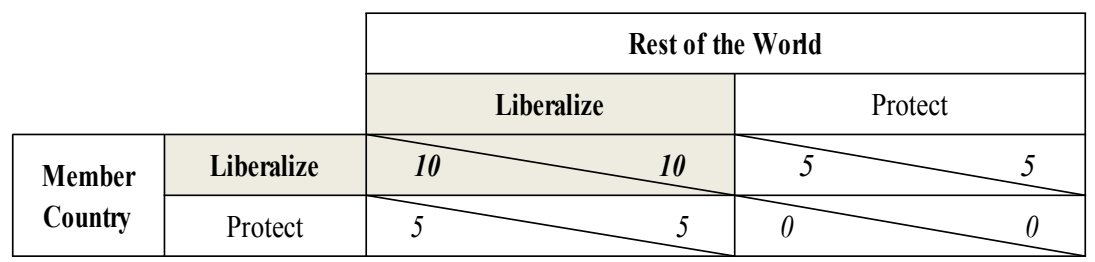

Figure 2.

Prisoners' Delight19)

17) While it is open to individual economies in isolation to secure the benefits of unilateral liberalization, the 'concerted' aspect recognized the benefits of collective liberalization.

18) Ruggiero (1996)

19) Garnaut (1996) 
By acknowledging both principles, one states that the larger the pie the bigger the benefits and the fact that APEC is currently pursuing an ultimate goal of 'anti-free-rider open regionalism,' the gains from APEC-wide integration will exceed any existing formulation. A successful implementation of open regionalism will not only eliminate negative effects, such as the spaghetti bowl effects, which can take place within fragmented sub-regional arrangements, but also increase the welfare effects for the members while minimizing the mal effects experienced by non-members. Furthermore, the successful launch of any kind of economic arrangement among APEC members is very likely to trigger a domino effect in the world political economy. With the fear of being excluded from the main stream of a world trade pact, every open-economy will voluntarily join such a circle, of which the basic notion is to be 'open' to all non-free-riders, and, thus, enable global liberalization in the long run.

Despite the listed theoretical and substantive benefits expected from an APEC-wide economic integration, the process has been practically halted. The primarily reason for this is because APEC's fundamental principles of consensus, voluntarism and unilateralism are idealistically good but utterly difficult to practice. A primary example of this was the Early Voluntary Sectoral Liberalization (EVSL) ${ }^{20}$ ) package which was ambitiously initiated but ended in failure. The consequent forwarding of the tariff element of the EVSL to the WT $\mathrm{O},{ }^{21)}$ while APEC concentrates on non-tariff measures, facilitation and Ecotech elements, imprinted negative perception on APEC and seriously damaged its credibility. ${ }^{22}$ ) Tied with the absence of a clear definition of a fundamental goal and open regionalism, APEC, unfortunately lost its momentum and was unable to push the involved leaders to reach a consensuses on the path to accomplish APEC-wide integration.

Furthermore, the growing political interferences in the trade environment, including security issues, have envisaged so much since the early 1990's when APEC was first formulated that the overall integration process has been consequently affected. In particular, the September 11 Incident forced the member states to regularize security related

20) EVSL is to liberalize 15 areas before the agreed goal of 2010 for industrialized economies and 2020 for developing economies in APEC. 15 areas APEC leaders agreed to liberalize in Vancouver were chosen from 60 sectors proposed by member economies and comprised of toys, fish and fish products, environmental goods and services, chemicals, forestry products, gems and jewelry, energy sector, medical equipment and instruments, telecommunications mutual recognition arrangement, food sector, natural and synthetic rubber, fertilizers, automotive, oilseeds and oilseed products, and civilian aircraft. Detailed targets and timetables for the first nine, the priority sectors, which were to be determined in 1998 were never agreed upon due to the strong reservations by Japan for its fisheries and forestry sectors.

21) This APEC's momentum of liberalization, especially the determination to forward the tariff element to the WTO, at least succeeded in launching the Doha Development Agenda in November 2001, following their declaration 'to start New Millennium Round' in 2000

22) $\operatorname{Nam}(2000)$ 
discussions at the regional level: anti-terrorism and trade-related security issues (Shanghai Leader's Meeting, 2001), secure transportation on both air and maritime basis, anti-money laundry and anti-cyber terrorism mechanisms (Los Cabos Leaders' Meeting, 2002), and bio-terrorism, weapons of mass destruction (WMD) and Man-Portable Air Defense Systems (Bangkok Leaders' Meeting, 2003) under the announced initiative of Secure Trade in the APEC Region (STAR). ${ }^{23}$ ) Yet, a skeptical view on the capacity of APEC to play a constructive role in political and security issues has prevailed. One of many defects APEC holds with regard to the political community aspect is its notion of openness. Since the portion of extra-regional members to whom Asian security issues are not 'reregional' can only increase once the membership reopens, from the current three (Chile, Mexico and Peru), APEC is not suited for this role. Furthermore, the likelihood of the People's Republic of China participating actively in any security dialogue with Chinese Taipei must be thoroughly assessed since the significance of China in addressing any kind of security issues in Asia, especially in relation to North Korea, is undeniable.

In spite of the aforementioned factors, the failure to embrace political flavor, or more specifically the limited influence of the US' hegemonic power in various negotiations including EVSL, to effectuate APEC as an institutional body is rather ironic considering that it had succeeded within various regional bodies and existed through the Cold War when the US' status as a regional military and economic superpower in the Asia-Pacific region was indisputable. The best explanation for this somewhat unexpected defensive posture by the US toward APEC during the 1990's would be its opportunistic liberalization policy. ${ }^{24)}$ According to this scenario, the US simply did not reject the offer to maintain its foothold in emerging regionalism in East Asia while the smaller countries, who drove the development of APEC in the initial days: the six ASEAN members ran into APEC to ensure their survival under Asian style export-driven economic development by diminishing market openness pressure ${ }^{25}$ ) while Australia promoted APEC, especially to the US, so as to avoid isolation between exclusive Asian and North American blocs. Such

23) STAR initiatives were agreed to secure the flow of goods and people through measures to protect cargo, ships, international aviation and people in transit. As a follow up, the STAR Conferences, comprising public and private sectors were held in Bangkok and Vina del Mar in 2003 and 2004 respectively.

24) It is a term given by Aggarwal and Lin (2002) to 'strategy without vision' trade policy that the US has embraced in the post-Cold War era. It describes inconsistent trade policy with which the US alternated among bilateral, minilateral and multilateral approaches whenever an earlier commitment runs into obstacles. Greatly owing to the structural limitation of the US, multiple priorities and points of interest group access, the trade policies were not able to attain a singular goal unlike during the Cold War era when a clear issue hierarchy of security and broader economic goals before more literal and provincial commercial interests were in place.

25) ASEAN countries had perceived US trade strategy as heavy-handed in its reliance on the use or threat of use of Super 301 clause of the Omnibus Trade and Competitive Act in particular (Plummer, 1998). 
unclear and reactive trade policy towards the Asia-Pacific region became obvious with the disappointing initial responses from the US and APEC at the outbreak of the 1997 Asian Financial Crisis. Despite the fact that the US was reluctant to financially participate in the Thai rescue package, it also rejected the Japanese proposal to compose an Asian Monetary Fund (AMF) of 100 billion USD. With the unexpected crisis, three positions were clearly visualized: Japan offered the creation of the AMF in hand with the IMF, Malaysia wished to establish a regional fund independent of the IMF, and the US opposed the idea of an institutional rivalry with the IMF. Although the AMF was held back with the endorsement of the Manila framework ${ }^{26)}$ at the 1997 Vancouver APEC Summit, the incident greatly affected both ends of APEC: the US, having encountered an obstacle in the multilateral open regionalism under APEC, which began to shift towards multilateral trade liberalization under the WTO while the East Asian countries launched the ASEAN+3 Summit as a response to the general needs of the regional body to jointly address regional issues.

\subsection{ASEAN-driven Intra-regional Institutionalization}

The end of the Cold War in December 1991 meant the restoration of the broken diplomatic relations among the Asian countries. In specific, the collapse of the former Soviet Union called upon two distinctive incidents in Asia: the formation of today's ASEAN with 10 member states through reconciliation between the ASEAN6 (Brunei, Indonesia, Malaysia, Philippines, Singapore and Thailand), the CLMV (Cambodia, Laos, Myanmar and Vietnam), and the increased intra-regional economic dependence marked with China's Open Door policy.

The Northeast Asian countries, including China, still remain somewhat distant with regards to the regional cooperative atmosphere which was driven by ASEAN until the 1997 Asian Financial Crisis. ${ }^{27}$ ) For this reason, an Asia-Europe Meeting (ASEM) was launched in 1996, a year before the first ASEAN+3 Summit. Ironically, Japan, who refused to participate in any exclusive Asian mechanism emphasized the 'Asian identity' in opposition

26) It called for IMF to take the lead in providing emergency loads to Thailand, Indonesia and Korea on conditionality, with APEC member nations taking only a secondary role, if necessary, to supplement IMF resources on a standby basis without any formal commitment of funds.

27) The launch of East Asia Economic Caucus (EAEC) or East Asia Economic Group (EAEG) proposed by former Malaysian Prime Minister Dr. Mahthir bin Mohamad in 1990 to encompass ASEAN and three Northeast Asian countries (China, Japan and Korea) was never fully realized due to Japan's refusal to participate. The idea of formulating an annual forum among the Asian countries as to balance the exclusive regional blocs of EU and NAFTA was only realized at the outbreak of 1997 Asian Financial Crisis: ASEAN+3 Summit. 
to the Europeans. Kiichi Miyazawa, the Japanese Finance Minister, remarked that this inter-regional forum was an opportunity for 'we East Asians to meet with you Europeans. ${ }^{28)}$ Accordingly, some social constructivists argue that the ASEM process has played a vital role in forming East Asia's regional identity and, hence, East Asian regionalism per se. With this new sense of 'regional identity' and the changes in the environment due to the Asian Crisis which occurred in 1997, an independent regionalization movement was initiated in East Asia. In other words the Leaders, being disappointed with the Western blocs during the 1997 crisis, acknowledged the high risk level of the fragmented region.29) Under many dedicated attempts from Malaysia, efforts to integrate East Asia continued with various proposals at different venues: a creation of the ASEAN+3 Secretariat (2002) at the ASEAN+3 Summit and a hosting of the First East Asia Congress (2003) under the title of 'Building The East Asian Community: The Way Forward.'

Unfortunately, the defensive regionalization displayed by East Asia, failed to materialize into any substantial regional cooperative mechanism due to various obstacles. The most economically probable one is the continued heavy reliance on the ex-regional developed economies as the final destinations for final goods. This means that the development of intra-regional trade in the form of the regional production network (RPN) excessively depends on the external market, and that direct investment in these regions aim chiefly at the transfer of the export production bases. In this light, these countries are to benefit if the East Asian regional bloc formation is WTO-friendly in order to avoid the spaghetti bowl effects. Otherwise, the complexity of the rules of origin which will result from the increasing number of bilateral FTA's between East Asian countries will become a barrier to intra-regional trade while serving as an obstacle towards efficient RPN. On the other hand, the strong opposition from the US posed such a great political burden to the involved countries ${ }^{30}$ ) that the membership of the East Asian Summit expanded to ASEAN+6 in 2005, diluting the original principle of deepened cooperation among the ASEAN+3 countries. ${ }^{31)}$ Former Malaysian Prime Minister Dr. Mahathir bin Mohamad made the following comments regarding this issue: (2006:13),

\footnotetext{
28) Financial Times (January 16, 2001)

29) Petri (1993)

30) Dent (2008)

31) According to James Baker (1995), US Secretary of State, US pressurized both Japan and Korea to lobby against Malaysia's EAEC initiative. Especially, to Korean Foreign Minister, Lee Sang Ok ,who suggested that his government might support Malaysia, Baker reminded him of the Korea-US Military Alliances and that 'all countries are not equal.'
} 
For reasons we could not understand, the US objected strongly to the EAEG. James Baker, who was then the US Secretary of State, visited South Korea and Japan and told them to have nothing to do with the proposal. Certain ASEAN countries were also advised not to support EAEG. It would seem in the US view that while European countries could get together, and Canada, the US and Mexico could form NAFTA, East Asian countries were not even allowed to talk to each other.

Such a restriction being imposed upon East Asia was great enough to affect even the Chiang Mai Initiatives (CMI), which is credited as one of the most successful regional which cooperative schemes in East Asia. The CMI is the only ASEAN +3 initiative which currently commits participating states to significant and reciprocal financial obligations on a regional basis. According to the current relatively strict conditions, only 20 percent of the initial swap arrangements under CMI can be released unconditionally without the approval from the IMF. In other words, the beneficiaries are obliged to respect the economic reform program recommended by the IMF in order for further assistance to be executed. Additionally, under the current policy objectives of the CMI framework, joint efforts regarding crisis prevention in the region are too ambiguous to be a mission statement toward regional economic integration. In the absence of a clear vision on the scope and modality of financial cooperation through the CMI, the current existing BSA's may not be effective enough to save any country facing an incipient crisis. The changes made to the $\mathrm{CMI}$ as a collective response regarding the need to upgrade the CMI operation for further financial integration in the East will be discussed in the next section.

Meanwhile, next in line is the Sino-Japanese relationship: hegemonic rivals or regional co-leadership? Due to the fact that the region's two great powers account for more than half of East Asia's total GDP, the impact of East Asia on the international system would be considerably diminished without either one of these countries. For that matter, many countries expect these two countries to cooperate in both leading regional affairs and representing the regional gains on an international level. Unfortunately, however, Sino-Japanese relations have historically been more competitive than cooperative ${ }^{32)}$ for various reasons despite the growing economic interdependence and deepening regional integration. Another obstacle which makes it significantly different for these two countries to cooperate naturally is that the national interests and regional strategies are very different for these two countries, making it even more difficult to achieve the same goal. China, who has played a comprehensively proactive role in international security matters from which

32) Such unpleasant relationship sparked when China refused to back Japan's application to become a permanent member of the UN Security Council and Japan likewise opposed to China's bid to accede to full membership of the G8 Group. 
Japan is restrained under certain constitutional constraints, is a permanent member of the United Nations Security Council and the host of the Six Party Talks on North Korean issues. Utilizing such experiences and global recognition, China has taken the lead on promoting closer security ties in the region. On the other hand, in 2001, China took a proactive role in both the establishment of the Shanghai Cooperation Organization ${ }^{33)}$ with Russia, Kazakhstan, Kyrgyzstan, Tajikistan, Uzbekistan and China, ASEAN, and simultaneously, in joining the Bangkok Agreement Free Trade Area with Korea, Russia and all of the other South Asian countries accept Japan. Furthermore, although China has continuously challenged Japan's economic leadership following Japan's economic malaise in the 1990's and China's recent economic boom, China is still a developing economy with a huge gap to narrow in terms of technological and industrial sophistication compared to Japan. On the contrary, Japan, the only Asian member state in the G7 and the largest donor of overseas development assistance (ODA) in Asia, thus far has maintained its position as the 'economic development role-model' in East Asia's flying geese pattern, since the early 19 century. Despite being at the forefront in supporting greater economic cooperation among the East Asian countries, Japan failed to extend its leadership regarding non-economic issues over its ambiguous perspective on the regionalization of East Asia. Apart from the vague geographical contiguity, ${ }^{34)}$ Japan is suspected to have maintaining its traditional pole position, by checking and balancing China's expansion, rather than sincerely working towards regional integration. ${ }^{35}$ ) These differences in the economic and military status of the two countries suggest that East Asia's regionalization may only become possible under a single countries strong leadership, at least, per field as China and Japan seem to find it difficult to cooperate on equal stances like France and Germany were able to do during the initial stages of the European integration. ${ }^{36)}$

The mal effects of internal rivalries such as the Sino-Japanese relationship also include the self-reinforcing mechanism between rivalries and bilateralism through which each country seeks to develop its own sphere of diplomatic alliances in order to gain an

33) In June, 2001, the presidents of five countries signed the Declaration of the Shanghai Cooperation Organization (SCO). The SCO aims at strengthening mutual trust and friendly relations among member states, encouraging their further effective cooperation in politics, economy, science and technology, culture, education, energy, transportation, environmental protection and other fields, jointly ensuring regional peace, security and stability, and creating a new international political and economic order.

34) Japan has been promoting regional integration among ASEAN $+5 / 6$ for which additional member states vary among Hong Kong, Taiwan, Australia, New Zealand and India depending on the occasion; ASEAN +5 with Hong Kong and Taiwan at Baoa Forum for Asia (2002), ASEAN+5 with Australia and New Zealand during his tour to Southeast Asia (2001) and ASEAN+6 with Australia, India and New Zealand at $38^{\text {th }}$ ASEAN Economic Ministers'Meeting(2006).

35) Koizumi Trade Pitch Misses by David Wall, the Japan Times, April 21, 2002

36) Park (2002) 
advantage and increase its influence in the region. For instance, Japan viewed China's FTA proposal to ASEAN ${ }^{37)}$ as an initial step towards regional hegemonic power in East Asia and immediately entered into counter-balancing FTA negotiations with ASEAN. If this continues to invite states to facilitate bilateral FTA's as reactive counter measures in relation to other states, a defensive and adversarial economic diplomacy environment could continue to make regional community building very difficult. The 'competitive bilateralism' could lead to undesirable ends: a 'hub-and-spoke' pattern within a region centering on dominating hub powers ${ }^{38)}$ and a Spaghetti bowl effect of cross-linked FTA's.

Above all, the absence of leadership imposes an even bigger problem than just regional competitive relationships. If the East Asian regional integration process is ever left for ASEAN to take the lead, further regionalization might be possible. This is due to the hard truth of ASEAN being a group of minorities, both in terms of politics and economic influence throughout the world, making them incapable of 'leading' three giants in Northeast Asia despite the early start. Past European experiences have also shown that any significant extension to establish any type of regional integrative mechanisms require leadership which fosters coherence among the involved member states by mediating between the divergent interests of the members. The most obvious case in hand for East Asia would be the CMI. Despite the fact that Japan is the only country with the capacity to increase the size of its bilateral swaps in the region in order to make the CMI a more credible financing scheme, not only does Japan's authority not allow this, but also no member states have invited Japan to do so. This is because Japan is very likely to demand the creation of an effective surveillance mechanism for the $\mathrm{CMI}$ in which it can exercise influence commensurate with its financial contribution, and China refuses to play second fiddle to Japan in any regional organization in East Asia. Under these circumstances in which no regional consensus even on an operational scheme of the CMI are met, further financial integration in East Asia seems very unlikely. In this sense, unless China, Japan and Korea, each identify appropriate roles and responsibilities to take up 'proactive' or 'passive' leadership roles in corresponding fields of cooperation, no regional integration will ever occur in an efficient or effective manner. In detail, occasional political conflicts involving territorial and historical perspective disputes, differences in political systems, and most importantly, lingering national sentiment towards the unsolved issues from the Second World War must be solved prior to effective regionalization talks taking place. Thus, a happy reconciliation among the three Northeast Asian countries from the wounds of the past is the key success factor for East Asian regionalization.

\footnotetext{
37) Kagami (2003)
}

38) Park (2008) 
So as to complicate the situation even further, the previously discussed ambiguity of the definition of East Asia as a region (East Asian identity) remains a great threat to East Asia's independent regionalization. The visualization of Japan's strategic interest in broadening the membership of the EAS can also be found in the mid-1990's when Tokyo had advocated the inclusion of Australia and New Zealand into the ASEM framework. On the other hand, China and Malaysia have traditionally displayed strong opposition on the membership expansion at least at the initial stages of regional integration. ${ }^{39)}$ The fact that CEPEA, which received a lukewarm response from China, was only passed to precede 'study but not necessarily to actually negotiate' illustrates the sensitivity of this issue. A number of countries already expressing their interest in joining EAS for which membership has been agreed to be frozen for the first two years at the least can only worsen the current situation. 40)

Such a diversion, prior to the solidification of any concrete building blocks to develop a regional community could result more difficulties, or at least lengthen the already difficult process. Because of the pre-discussed obstacles which pose threats to the regional integration in East Asia, a construction of a region-wide FTA on the basis of the existing FTAs, including ASEAN+1 FTA's as ASEAN might have hoped for, seems nearly impossible. Instead, a newly established region-wide FTA should overwrite the existing multiples of bilateral FTA's in order to effectively integrate the region. However, considering the diversified membership of East Asia as a region, proven by the degree of variation in the pre-effectuated FTA's among the member states, the creation of such a high quality region-wide FTA to replace all existing trade liberalization arrangements will not be an easy task. Hence, the new region-wide FTA should be 1) Relatively flexible with a tariff concession structure, 2) Simple and liberal regarding the rules of origin, 3) Strengthen trade and investment measures, and 4) Develop a concrete cooperation mechanism ${ }^{41)}$ for future expansion and evolution. In this light, it may be fair to state that a region-wide FTA is only possible with a de facto China-Japan-Korea FTA.

Given the current complex circumstances surrounding the region, the after-effects of the current global credit crunch should also be carefully examined. Among many speculated theories regarding the post-crisis, special attention must be paid to following aspects which are directly linked to regional affairs. First of all, the new role, or the

39) Asahi Shimbun reported that "Beijing argued the greater the number of countries involved, the less integrated and coherent a future East Asian community will be" on January 4, 2005

40) These countries include Russia (observer status gained at the first EAS whose full membership is strongly supported by China), Pakistan and Mongolia (supported by Malaysia), and Papua New Guinea (supported by Australia). Furthermore, both the EU and the US have expressed their wish to be granted at least the observer status.

41) Lee (2006) 
position, of the US in the world, and especially in East Asia, is the key concern since the objection of the US has traditionally served as one of the major obstacles as mentioned before. It would be most desirable to shape the new role of the US to East Asia's liking, whenever possible, including its relations with the three Northeast Asian countries. Furthermore, the re-drawing of world economic geography, which is still in connection with the new role of the US, is also crucial. Whether the heavy reliance toward the US market as the major final goods destination is maintained even after the crisis in the East Asian production network will determine the new coefficients of expected gains/losses of the pre-discussed East Asian integration paths.

\subsection{Global Credit Crunch}

Although it is too early to determine the overall impact of the 2008 credit crunch which is currently effecting the global trade environment, this section will attempt to provide some prospects for the US, especially, in relation to the East Asian regionalization process. Since the identification of the origin or the progress of the crisis itself is beyond the scope of this paper, the controversial issues regarding those topics will not be discussed here. Instead, the focus will be on the impact of the crisis with regards to the East Asian regionalization process beginning with the assumption that the crisis has triggered the current global recession, which has spread across both the financial and manufacturing sectors. 42 )

Economic crises in the modern world always have a political impact as the biggest capitalist concerns still operate from national bases. Despite all the hype regarding globalization, economic crises still result in defensive economic policies in order to defend national interests from rival multinationals from other states. ${ }^{43)}$ Under these circumstances, especially, the policy discords among states often behave as obstacles to quick economic recovery and power struggles become most visible. Traditionally, the US, being a hegemonic power, experienced no difficulties in exerting pressure on its major trade partners (Japan, Korea and the EU) to align their trade and other related policies with that of the US for the synergic effects. ${ }^{44)}$

42) Nouriel Roubini of New York University's Stern School of Business sees that "a rising probability of a catastrophic financial and economic outcome" with "a vicious circle where a deep recession makes the financial losses more severe and where, in turn, large and growing financial losses and a financial meltdown make the recession even more severe" as quoted by Martin Wolf, Financial Times, 19 February 2008.

43) Chris Harman (2008)

44) One of the well known cases is the Plaza Accord of 1985. This agreement was signed among France, West Germany, Japan and the US and the UK to depreciate the US dollar in relation to the Japanese Yen 
The prospect of the US's international relations solution to create a breakthrough in the economic crises, however, does not seem bright with regards to the current Global Credit Crunch which also took place back in the 1980's. This, is possibly one of the many reasons for the ongoing recession in the US, and can be explained by the newly emerging economic powers: BRIC's, whose dependency towards the US, both economically and militarily, is significantly lower than that of the previous economic growth engines, the Four Asian Tigers. ${ }^{45)}$ Although it was toned-down and has created less of a problem than many observers expected, the fact that the leaders of the developing countries, BRICs, expressed their frustration with the dominant but unstable dollar as the world's reserve currency and launched a Summit (BRIC's Grouping) to find a common base on which they could capitalize on their own growing economic influence ${ }^{46)}$ clearly demonstrates the changes occurring in the world order. Additionally, although the BRIC's grouping urged for a greater voice and representation within the international financial institutions and the emerging and developing economies, 2009 can be acknowledged as the year of the opening of the multi-polar system and the shifting away from traditional US hegemony with a de facto replacement of the G7 by the G20.

Consequently, the 2008 Global Credit Crunch is providing an opportunity for East Asia to increase its integrative initiatives, possibly more than that of the 1997 Asian Financial Crisis, because of the reduced hegemonic influence from the US. The first evidence can be found in the modified version of the CMI, Chiang Mai Initiative Multilateralization (CMIM), which was implemented on March 23, 2010 to replace the existing network of bilateral agreements with a reserve pooling arrangement totaling $\$ 120$ billion. If it is what many observers have interpreted it as, the CMIM will be the first, yet critically major, step towards the inevitable fulfillment of the 1997 proposal to create an Asian Monetary Fund (AMF) which will be independent from the influence of both the IMF and the US. Furthermore, the US becoming the $16^{\text {th }}$ non-Southeast Asian country to accede to the Treaty of Amity and Cooperation (TAC) ${ }^{47)}$ on July 22, 2009 epitomizes the

and German Deutsche Mark by intervening in currency markets. The exchange rate of the dollar to the yen declined by $51 \%$ between 1985 and 1987 following carefully planned and pre-announced devaluation process. Such dollar's devaluation was requested by the US for the two main purposes: 1) to reduce the US current account deficit, which had reached $3.5 \%$ of the GDP, and, 2) to help the US economy to emerge from a serious recession that began in the early 1980s. Louvre Accord was signed in 1987 to terminate the dollar devaluation process, and with the inclusion of Japan in both negotiations Japan was widely acknowledged as a real player in managing the international monetary system.

45) Four Asian Tigers refer to four East Asian countries with successful economic development histories (Hong Kong, Korea, Singapore and Taiwan). Due to geopolitical reasons, all four countries have established close partnership with the US that their trade related policies are highly influenced by the US government as Japan and the EU has been so.

46) BRICs group takes a shot at USD supremacy by Kris Roman from Rusmedia, June 22, 2009 (http://eurorus4en.wordpress.com/2009/06/22/bric-group-takes-a-shot-at-usd-supremacy/) 
shift of strategy of the Obama administration towards ASEAN, and Asia in a broader term. Secretary of State Hillary Roadham Clinton announced that the Administration pursued accession to the Treaty because "we believe that the US must have strong relationships and a strong and productive presence here in Southeast Asia." ${ }^{48)}$ With this, the US has satisfied all the criteria required for the East Asia Summit and now the question lies whether the US will extend its participation to the Summit or not. If the US decides to join the Summit, it will be to ensure the compatibility of the proposed Comprehensive Economic Partnership in East Asia within the EAS with the Free Trade Area of the Asia pacific within APEC, after its long tradition of avoiding commitment outside of the North American region.

An additional driver towards the economic integration to create a larger intraregional' market can be found within the rising trade barriers with increasing voices which favor protectionism as the economic recession deepens. As reflected in the Joint Remarks by Korean President Lee, Myung-bak and US President Obama on June 16, 2009,49) the world is going against the past efforts to realize the free-r trade environment facing the greatest economic crisis ever. A number of countries have raised import duties or passed stimulus measures with trade-distorting subsidies as the World Bank, in a report in March 2009, announced the adoption of 47 new trade restrictive measures as a means to 'support' domestic economies by 17 members of the G20.50) Although the Obama administration persuaded Congress to water down the "Buy America" provision in the stimulus package that was intended to ensure that only American manufacturers benefited from publicspending projects, ${ }^{51)}$ the US has not been an exception from this trend and has issued various bailout schemes to revive its Auto and finance industries. This rise in protectionism tied with dramatic cuts in the consumption ratio in the developed markets, especially the US, and the exceptionally high dependency of the East Asian countries on the extraregional markets have been forced to be reduced since 2008. Such a bottom-up procedure to

47) The Treaty is a peace treaty first enacted among Southeast Asian countries by the founding members of the ASEAN. With the amendment on December 15, 1987, accession by states outside the region became possible, and China was the first one to join on October 8, 2003. The purpose and principles of the Treaty and its provisions for the pacific settlement of regional disputes and for regional cooperation in order to achieve peace, amity and friendship among the peoples of Southeast Asia in accordance with the Charter of the United Nations.

48) United States Accedes to the Treaty of Amity and Cooperation in Southeast Asia, Fact Sheet published on July 22, 2009 (http://www.state.gov/r/pa/prs/ps/2009/july/126294.htm)

49) Joint Remarks by Korean President Lee, Myung-bak and the US President Obama at the press conference in Washington on June 16, 2009 (http://www.cfr.org/publication/19646/)

50) Russia has raised tariffs on used cars; China has tightened import standards on food, banning Irish port; India has banned Chinese toys while Argentina has tightened licensing requirements on auto parts, textiles and leather goods.

51) Trade Barriers Rise as Slump Tightens Up by Mark Landler, March 22, 2009, The New York Times (http://www.nytimes.com/2009/03/23/world/23trade.html) 
shift towards the intra-regional market for the economic survival continues for long enough for the regional architecture to catch up; (I don't know what this is trying to say) the current global recession might become the cornerstone of the introduction of a single market in East Asia.

On the other hand, China, whose official holdings of US Treasury bills increased by $50 \%$ in the year 2009 alone, has hinted about its ambition to replace the greenback with its redbacks (Yuan), or more familiarly with some 'supranational' currency such as Special Drawing Rights (SDRs), the unit of account at the International Monetary Fund. ${ }^{52}$ ) There are analysts who currently argue that such complaints from China are simply empty political pressure being placed on the US, and that Chinese policymakers are not ready to take the necessary steps to internationalize the Yuan as the world currency because this would include the adaptation of a floating exchange rate. Although this might be true that the world might need another decade before actually witnessing the reds overwriting the greens in international trade, the dramatic elevation of China's significance in the world economy, and hence, in East Asia cannot be denied. Should this relative rise of China's influence intensify the Sino-Japanese rivalry or any other conflicts in the region, East Asia might experience an escalated race for competitive bilateralism rather than the desired cooperative regionalism.

Likewise, the impact of the current economic circumstances on the East Asian regionalization process has yet to be determined and the question of whether to use it as a driver or leave it to become an obstacle lies in the hands of the involved countries. The year $22^{\text {nd }}, 2011$ APEC Summit is scheduled to be held back in the US having gone round 21 member states and the $14^{\text {th }}$ anniversary of ASEAN +3 , offer some critical decision-making opportunities for Leaders on whether to facilitate their individual experiences of bilateral trade negotiations in order to break through the deadlock of regional-based integration or to continue its dependency on the private business networks in order to comply with the key decisions regarding international economic issues which have been made elsewhere. In this light, the future progress of the currently ongoing discussion regarding the Korea-ChinaJapan FTA, either towards the WTO-based multilateral economic cooperation or towards a hub-and-spoke structure at the expense of the existing ASEAN+1 FTA's, is of great interest.

52) China's Plans for Replacing the Dollar by Michael Schuman, July 21, 2009, Times (http://www.time. com/time/world/article/0,8599,1911671,00.html) 


\section{Conclusion}

Since as early as the 1960 's, there have been common understandings and reasons to form a regional cooperative body in East Asia. It has only been due to complicated global circumstances which have taken place in the region geographically, as highlighted in the two military conflicts which broke out on the Korean Peninsula and in Vietnam during the Cold War, which prevented the neighboring countries from materializing any official initiatives. Coincided with the urgent need for economic growth, the pursuit of open regionalism advocated by the major markets, the US and the EU, is a natural choice for the export-oriented economies in East Asia. Hence, the past period was devoted to each government building its economy and getting what it required to experience exceptional economic growth with little or no effort being dedicated to 'regional market making.'

However, the lack of support and assistance which has recently been offered by the Western economies in the wake of the 1997 Asian Financial Crisis taught the East Asian region leaders the need for an institutionalized cooperation exclusively for East Asian economies. A major outcome resulting from this cognitive shift was the formulation of the ASEAN+3 Summit. The successful involvement of both China and Japan is an accomplishment in itself as it suggests a potential solution to the traditional Sino-Japanese rivalry. Moreover, the grouping of all 13 economies in the region has benefited each government with an increased share of world trade due to its effects in the regional production network. Yet most importantly, it has provided a springboard from which to launch a series of new regional initiatives: the Chiang Mai Initiative (2000) and the Asian Bond Markets Initiative (2003). 53)

Unfortunately, the region has failed to reach a consensus on the paths and the driver for the regionalization process for various reasons. Firstly, due to the absence of a clear definition within the region, the scope of integration is still blurry with three likely candidates: an APEC-driven system or an ASEAN-driven system for ASEAN+3 or ASEAN+6. Secondly, an export-oriented economic structure with an exceptionally high dependency towards non-regional economies such as the US and the EU, which undeniably drive local governments to favor the multilateral trade agreements over the narrowly specified regional blocs. In this light, the regional integration process in East Asia is inevitably venerable to the ex-regional influences. Thirdly, the historical disputes and conflicts among member states including the North Korea issue impede the progress of cooperative coordination in the region. Along the same line, the absence of regional leadership, reflected in the long traditional Sino-Japanese rivalry, imposes a large threat to

53) Davies (2010). 
the launch of any successful institutional mechanism being implemented in the region. Last but not least, the ambition and interest which the US holds in the region further complicates these issues. Due to the established strong economic, political and military partnerships between the two major economies, Japan and Korea, and the US, the regional integration process has not been totally free from US influence thus far.

On an account of the last point regarding the US, the 2008 Global Credit Crunch may serve as a more critical pivotal point than the 1997 Asian Financial Crisis had been in the progress of the East Asian regionalization. Although it is still too early to conclude the impact of the incident, the after effects are still easily found worldwide and two phenomena seem to be rather certain: the fall of the US from its traditional status as a hegemonic power and the rise of the developing economies as reflected in the replacement of the G7 by the G20. It has been evident on many occasions that the Obama administration is practicing a new foreign policy with an increased emphasis on the Asian region in order to accede to the Treaty of Amity and Cooperation in 2009 as a demonstration of its dedication to remain present in the region. On the other hand, a successful launch of the Chiang Mai Initiative Multilateralization (CMIM), which is interpreted as a first step towards the establishment of the Asian Monetary Fund (AMF), symbolizes a more aggressive driver towards a regionalization free of US interferences. Although the US currently maintains its standpoint regarding inter-regional market liberalization, the direction of the East Asian regionalization may be determined irrespectively by the continued rise of China's global status and its increasing economic power. In this regard, it will be noteworthy to watch how the world breaks through the current Global Credit Crunch in relation to the progress which is being made in East Asian regionalization. 


\section{References}

Baldwin, Richard E. (2007), The Spoke Trap: Hub-and-Spoke Bilateralism in East Asia from China, Asia and the New World Economy with Barry Eichengreen, Yong-chol Park and Charles Wyplosz, Graduate Institute of International Studies, Geneva, February

Beeson, Mark (2004), Re-thinking Regionalism: Europe and East Asia in Comparative Historical Perspective, Oceanic Conference on International Studies, Canberra, July 14-16

Bhagwati, J., Free Trade Today, Princeton, NJ: Princeton University Press

Choi, S., Revisiting the Open Regionalism of APEC - Assessment and New Challenges, KIEP, APEC Study Series 04-01

Davis, J. Ryan, East Asian Regionalism: Origins, Development and prospects for the Future, Politikon (IAPSS), Vol. 16(1), 2010, pp.34-49

Dent, Christopher M. (2008), East Asian Regionalism, Routledge

Garnaut, R. (1996), Open Regionalism and Trade Liberalization: An Asia-Pacific Contribution to the World Trade System, Institute of Southeast Asian Studies, p. 1-41

Harman, C. (2008), From the Credit Crunch to the Spectre of Global Crisis, International Socialism, Issue 118, March

(http:/www.isj.org.uk/index.php4?id=421\&issue=118118 harman_33\#118harman37)

Kagami, M. (2003), ASEAN-Japan Comprehensive Economic Partnership and Japan's FTAs with other countries including Korea and Mexico, presented at the JEF/SIIA International Symposium, Singapore, March 7-8

Lee, Chang Jae and Hyung-Gon Jeong (2006), From East Asian FTAs to an EAFTA, KIEP, Policy Analysis 06-01, December

Mahathir, M. (2006), Let Asians build their own future regionalism, Global Asia, 1, 1:13-15

Nam, S. (2000), APEC Trade Liberalization after EVSL, KIEP APEC Study Series 00-07

Park, I.W. (2008), Regional Trade Agreements in East Asia: Will they be sustainable? Korea University, February

Park, Y. and Yunjong Wang (2002), Can East Asia emulate European economic integration? KIEP Discussion Paper 02-09, November 
Petri, Peter A. (1993), The East Asian Trading Bloc: An Analytical History from Regionalism and Rivalry: Japan and the United States in Pacific Asia edited by Jeffrey A. Frankel and Miles Kahler, Ch.1, pp.21-51

Ruggiero, R. (1996), Next Steps in Strengthening the Global Trading System, Speech given at North American dinner in New York City, April 17

Yip, Wei Kiat (2001), Prospects for Closer Economic Integration in East Asia, Greater East Asia, Stanford Journal of East Asian Affairs, 1:106-111, Spring

\section{Websites:}

Official Statistical Data Banks

Korea: http://www.kita.net

World:

http://comtrade.un.org/db/default.aspx (UN Comtrade)

http://stats.unctad.org/fdi/ReportFolders/reportFolders.aspx (UNCTAD FDI)

http://www.worldbank/org/ (World Bank)

http://www.cia.gov/library/publications/the-world-factbook/ (World Factbook)

Official FTA homepages

Japan: http://www.mofa.go.jp/policy/economy/fta/

Korea: http://www.fta.go.kr/user/index.asp

US: http://www.export.gov/fta/ 
